\title{
Reproductive parameters of Sindhi cows (Bos taurus indicus) treated with two ovulation synchronization protocols
}

 \\ Ana Paula Toledo Barbosa da Silva ${ }^{1}$, Leandro Mendes Mascarenhas ${ }^{1}$, Bernardo Janella \\ Ferreira da Silva ${ }^{1}$, Beatriz de Oliveira Cardoso ${ }^{1}$, Helcimar Barbosa Palhano ${ }^{2}$
}

\footnotetext{
${ }^{1}$ Departamento de Reprodução e Avaliação Animal, Instituto de Zootecnia, UFRRJ.

${ }^{2}$ Departamento de Biologia Animal, Instituto de Biologia, UFRRJ.
}

\begin{abstract}
The objective of this study was to evaluate the reproductive parameters of Sindhi cows aiming to improve the efficiency of fixed-time artificial insemination protocols in this breed. For this purpose, sixteen Sindhi cows were divided into two groups: in group I $(\mathrm{EB}, \mathrm{n}=8)$ animals received an intravaginal P4 implant and an application of 2 mg of estradiol benzoate on day 0 . On day 8 the implant was removed and $10 \mathrm{mg}$ of Dinoprost were applied; on day 9, $1 \mathrm{mg}$ of estradiol benzoate was applied, and animals were fixed-time artificially inseminated 36 hours later; in group II $(\mathrm{EB}+\mathrm{eCG}, \mathrm{n}=8)$ animals were subjected to same treatment, and on day eight $400 \mathrm{IU}$ of eCG were applied. From day 0 animals were examined daily by a trans-rectal ultrasound device, where in each assessment the largest follicles of each day were measured. The reproductive parameters observed for groups I and II were: emergence of follicular wave, $4.5 \pm 1.4$ and $3.8 \pm 0.3$ days; interval between wave emergence and ovulation, $5.8 \pm 1.4$ and $7.1 \pm 0.3$ days; interval between wave emergence and implant removal, $3.5 \pm 1.4$ and $4.1 \pm 0.3$ days; interval between implant removal and ovulation, $74.0 \pm 11.8$ and $82.5 \pm 4.2$ hours; diameter of the dominant follicle (DF) at the time of implant removal, $7.5 \pm 2.5$ and $6.6 \pm 1.5 \mathrm{~mm}$; maximum diameter of DF, $10.47 \pm 8.85$ and $3.7 \pm 1.2 \mathrm{~mm}$; growth rate of DF, $0.90 \pm 0.83$ and $0.7 \pm 0.6 \mathrm{~mm} /$ day; ovulation rate, $75 \%$ and $100 \%$; and pregnancy rate, $0 \%$ and $50 \%$, respectively. There was no significant difference between the groups. We observed that eCG was not efficient in improving the reproductive parameters analyzed in this breed.
\end{abstract}

Key Words: eCG, follicular growth, reproduction, zebu

\section{Introduction}

The Brazilian cattle herd consists of more than 200 million of animals (MAPA, 2010), and zebu cattle corresponds to approximately $80 \%$ of that heritage. The prevalence of this genetic group is due to greater availability of food found in tropical Brazil (Baruselli et al., 2007). However, in the vast majority of Brazilian cattle there are many difficulties for an accurate heat detection, which affects the reproductive efficiency of the herd (Baruselli \& Marques, 2002).

To avoid the problem of estrus detection in herds of zebu cattle, protocols for estrus and ovulation synchronization, which allow for inseminating a large number of animals within a predetermined time, were developed (Bó et al., 2004). These treatments are known as protocols for fixed-time artificial insemination (FTAI), and are divided between those using combinations of GnRH and PGF2 $\alpha$, and using devices with progesterone and estradiol (Baruselli \& Marques, 2002). Despite the high levels of estrus and ovulation synchronization achieved with the various existing treatments, the results are not always translated into pregnancy (Porto Filho, 2004).
In cattle, there are some factors that may contribute to the reduction of fertility, such as postpartum anestrus, low nutritional status (Bó et al., 2001) and low plasma concentrations of progesterone (Binelli et al., 2001).

Thus, strategies that produce high concentrations of $\mathrm{P} 4$ may be critical to inhibit the synthesis of PGF2 $\alpha$, which usually occurs during the critical period of gestation. In this context, the equine chorionic gonadotropin (eCG) could be used to stimulate the production of $\mathrm{P} 4$ by corpora lutea (CL), increasing plasma concentrations of $\mathrm{P} 4$ in subsequent estrous cycles (Baruselli et al., 2000).

The Sindhi zebu breed, originated from an arid region of Pakistan, has excelled in milk production (Santiago, 2009). Although much research is being developed with the Sindhi breed, such experiments are focused predominantly on aspects of animal production. Studies involving the reproductive tract of the Sindhi zebu breed, especially those related to reproductive biotechnologies, are still scarce (Carvalho, 2009).

The objective of this study was to evaluate the reproductive parameters of Sindhi cows subjected to an 
ovulation synchronization protocol so as to improve the efficiency of this FTAI protocol in this breed and contribute to an effective diffusion of genetics of these animals.

\section{Material and Methods}

This experiment was carried out at the Department of Animal Evaluation and Reproduction, Institute of Animal Science at Universidade Federal Rural do Rio de Janeiro, located in the city of Seropedica, state of Rio de Janeiro, Brazil, from January 10 to February 11, 2011. Sixteen nonlactating, non-pregnant Sindhi (Bos taurus indicus) cows, with a body condition score between 3.0 and 4.0 on a scale from 1.0 to 5.0 (Wildman et al., 1982), registered in the Brazilian Association of Zebu Breeders and aged between 3 and 17 years were used.

All animals were previously subjected to gynecological examination by rectal palpation to detect cyclicity and reproductive tract abnormalities. During the experiment, the animals were kept confined in the Department of Animal Breeding and Evaluation, where they had access to Brachiaria decumbens grass pastures and water ad libitum.

The methodology used to assess the reproductive parameters was proposed by Porto Filho (2004). Cows were first synchronized with two applications (im) of $2 \mathrm{~mL}$ of PGF $2 \alpha$ (Lutalise $^{\circledR}$ ) with an interval of 14 days. Seven days after the second application of PGF $2 \alpha$, cows were divided into two groups according to assessment age, undergoing treatments to synchronize ovulation. In Group I $(\mathrm{EB}, \mathrm{n}=8)$, the animals received an intravaginal silicone implant impregnated with $1.9 \mathrm{~g}$ of progesterone $\left(\mathrm{CIDR}^{\circledR}\right)$ and an application (im) of $2 \mathrm{mg}$ of estradiol benzoate (EB, Estrogin ${ }^{\circledR}$ ) on day 0 . On day 8 , the intravaginal implant was removed, and $10 \mathrm{mg}(\mathrm{im})$ Dinoprost $^{\mathbb{B}}$ (PGF2 $\alpha$ ) were applied. After 24 hours, $1 \mathrm{mg}$ (im) of estradiol benzoate was applied. Fixed-time artificial insemination was performed 36 hours later (Figure 1).

In Group II (EoB $+\mathrm{eCG}, \mathrm{n}=8)$, the animals received an intravaginal silicone implant impregnated with $1.9 \mathrm{~g}$ of progesterone $\left(\mathrm{CIDR}^{\circledR}\right)$ and an application (im) of $2 \mathrm{mg}$ of estradiol benzoate (EB, Estrogin ${ }^{\circledR}$ ) on day 0. On day 8 , the intravaginal implant was removed, and $10 \mathrm{mg}$ (im) of Dinoprost ${ }^{\circledR}$ (PGF2 $\alpha$ ) and 400 IU of equine chorionic gonadotropin (eCG, Novormon ${ }^{\circledR}$ ) were applied. After 24 hours, $1 \mathrm{mg}$ (im) of estradiol benzoate was applied, and FTAI was performed 36 hours later (Figure 2).

Ultrasonographic examinations were performed by transrectal technique with a $7.5 \mathrm{MHz}$ linear-array transducer (CHISSON $^{\circledR}$ D600 VET), and began on day 0 of the synchronization protocol, repeated every 24 hours. In each assessment, the largest follicle of each day with a diameter greater than $4 \mathrm{~mm}$ was measured by the ultrasound of the device itself to monitor the follicular growth and determine the maximum diameter of the dominant follicle (DF). After the second application of EB (day 9), the animals were assessed by ultrasound twice daily (every 12 hours) until ovulation was detected, and then subjected to FTAI 36 hours later. The reproductive parameters evaluated were: emergence of follicular wave (days); interval between wave emergence and ovulation (days); interval between wave emergence and implant removal (days); interval between implant removal and ovulation (hours); diameter of DF at the time of implant removal (mm); maximum diameter of DF (mm); growth rate of DF ( $\mathrm{mm} /$ day); ovulation rate $(\%)$; and pregnancy rate (\%). Pregnancy diagnosis was performed by ultrasonography (CHISSON ${ }^{\circledR}$ D600 VET) 55 days after FTAI.

Data were analyzed using the software Sistema para Análises Estatísticas e Genéticas (SAEG, version 9.1). Differences between groups (mean \pm standard deviation) were tested by general linear model of variance (ANOVA), and the treatment means were compared by the Tukey test at a significance level of $5 \%$. To analyze the ovulation and pregnancy number in different groups, descriptive statistics were used through histogram and frequency table. In the variance analysis the effects of categorical variables treatment I (Group I: without eCG) and treatment II (group II: 400 IU eCG) were analyzed. The response

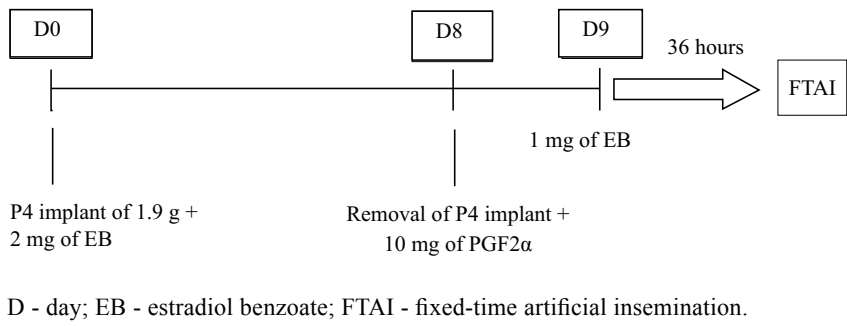

Figure 1 - Scheme of ovulation synchronization without the use of eCG.



Figure 2 - Scheme of ovulation synchronization with eCG. 
variables analyzed in the experiment were: emergence of follicular wave (days); interval between wave emergence and ovulation (days); interval between wave emergence and implant removal (days); interval between implant removal and ovulation (hours); diameter of DF at the time of implant removal $(\mathrm{mm})$; maximum diameter of DF $(\mathrm{mm})$; growth rate of $\mathrm{DF}(\mathrm{mm} /$ day); ovulation rate $(\%)$; and pregnancy rate $(\%)$.

\section{Results and Discussion}

There was no statistical difference $(\mathrm{P}>0.05)$ for groups I (without eCG) and II (400 IU eCG) in relation to emergence of follicular wave; interval between wave emergence and ovulation; interval between wave emergence and implant removal; interval between implant removal and ovulation; diameter of dominant follicle (DF) at the time of implant removal; maximum diameter of DF; and growth rate of DF (Table 1).

The ovulation synchronization protocol based on the use of progesterone and estradiol used in this study has been widely discussed in the literature (Porto Filho, 2004). The effects attributed to these hormones, such as atresia of FSH and LH-dependent follicles and ovulation in a predetermined time, resulting in the emergence of a new wave of follicular growth and in the ovulation synchronization, are reported by several researchers (Bó et al., 1994; Bó et al., 1995; Driancourt, 2000; Rocha, 2000; Lane et al., 2001).

The results presented in this study regarding the emergence of follicular wave, in which $2 \mathrm{mg}$ EB were used at the beginning of treatment, are consistent with the findings of Bridges et al. (1999), who, evaluating 46 lactating beef cows at 28 days postpartum, obtained the emergence of a new follicular wave in $3.9 \pm 0.6$ days with the administration of $2 \mathrm{mg}$ EB at the time of progesterone implant. Similarly, Carvalho (2004) obtained the emergence of a new follicular wave in $3.3 \pm 0.3$ days in 12 Nellore cyclic heifers aged between 20 and 24 months with the administration of $2 \mathrm{mg} \mathrm{EB}$ at the time of progesterone implant. Thus, the results in this study corroborate the data cited in the literature (Bó et al., 1995), where treatments with progestogen and estradiol, like the use of intravaginal implants of $\mathrm{P} 4+\mathrm{EB}$, can promote synchronous emergence of a new wave of follicular growth 4 days after initiation of treatment, regardless of the developmental stage of the dominant follicle at the time of treatment (Table 1).

The elevations in blood concentrations of FSH are responsible for follicular recruitment, and an increased concentration of estrogen entails a negative response from FSH secretion (Carvalho, 2004). Evans et al. (1997) showed that androgen secretion is inversely related to circulating concentrations of $\mathrm{FSH}$, demonstrating that androgens regulate the pattern of fluctuation in the secretion of FSH and the emergence of follicular waves. According to Gibbons et al. (1999), estrogen plays an important role in the suppression of FSH. In the presence of high levels of P4 depending on the dose, estrogen also blocks the release of LH, and may influence the emergence of the subsequent wave of follicular growth (Carvalho, 2004). The variations observed on the day of emergence of follicular wave are associated with dose and preparations of estrogen used, such as estradiol benzoate (EB), estradiol valerate (EV) and estradiol cypionate (ECP), which can produce different effects on concentrations of gonadotropins (Carvalho, 2004). Given this variation, the close synchrony between the day of emergence of new wave of follicular growth between two groups suggests that the dose of $2 \mathrm{mg}$ EB (im) was adequate to maintain high concentrations of estrogen in the circulation. Treatment with $2 \mathrm{mg}$ EB, used at the moment the insertion of $\mathrm{P} 4$ intravaginal implant, can promote the emergence of a new wave of follicular growth in a range of 2 to 6 days after the beginning of treatment (Table 1).

Studies on animals show that treatment with $\mathrm{eCG}$ at the withdrawal of P4 intravaginal implant does not influence the interval between implant removal and ovulation (Baruselli et al., 2008); as observed in this experiment, no statistical difference was found between groups. Indeed, Marques et al. (2003); Sá Filho et al. (2004); Duffy et al. (2004); Souza et al. (2006); and Maraña et al. (2006) observed that the use of eCG did not influence the interval between removal of $\mathrm{CIDR}^{\circledR}$ and ovulation in female Bos taurus

Table 1 - Reproductive parameters of Sindhi cows treated with two ovulation synchronization protocols

\begin{tabular}{lrr}
\hline Parameters & Group I & Group II \\
\hline Emergence of follicular wave (days) & $4.5 \pm 1.4$ & $3.8 \pm 0.3$ \\
Interval between wave emergence and ovulation (days) & $5.8 \pm 1.4$ & $7.1 \pm 0.3$ \\
Interval between wave emergence and implant removal (days) & $3.5 \pm 1.4$ & $4.1 \pm 0.3$ \\
Interval between implant removal and ovulation (hours) & $74.0 \pm 11.8$ & $82.5 \pm 4.2$ \\
Diameter of the dominant follicle at the time of implant removal (mm) & $7.5 \pm 2.5$ & $6.6 \pm 1.5$ \\
Maximum diameter of the dominant follicle (mm) & $10.4 \pm 3.7$ & $8.8 \pm 1.2$ \\
Growth rate of the dominant follicle (mm/day) & $0.9 \pm 0.7$ & $0.8 \pm 0.6$ \\
\hline
\end{tabular}


taurus and Bos taurus indicus. Thus, the works contained in the literature indicate that treatment with progestogen, estradiol, and eCG can promote a synchronized ovulation in a range from 72 to 84 hours between P4 implant removal and ovulation in the treated animals. The wide variation observed in the results of the mean and standard deviation regarding the interval between $\mathrm{P} 4$ implant removal and ovulation between the groups can be explained by the fact that two animals of group I did not show ovulation during the experiment (Table 1). Treatment with eCG, at the time of P4 implant removal, can increase the growth rate of the follicles, resulting in a higher pre-ovulatory follicle and, consequently, a higher CL, or even stimulate the growth of several follicles that could be induced to ovulate (Porto Filho, 2004). Thus, eCG has been used to improve fertility rates due to an increase in ovulation rate and plasma concentrations of progesterone during the subsequent luteal phase (Sá Filho et al., 2010a). Accordingly, several authors have observed an increase in the follicular growth with the use of eCG in cattle (Marques et al., 2003; Baruselli et al., 2004b,c; Sá Filho et al., 2010a,b; Sales et al., 2011). However, no positive effect of eCG on the diameter of ovulatory follicle and on the follicular growth was verified in this study, with no difference between the groups (Table 1). This may be related to the fact that Sindhi cows were in good body condition score $(\mathrm{BCS} \geq 3.5$ on the scale from 1.0 to 5.0 ) during the experiment, and their estrous cycle (presence of a functional CL) was normal at the beginning of treatment, since the effect of eCG to stimulate follicular growth becomes more evident in animals with low body condition score and intense degree of anestrus $(\leq 2.5$ on the scale from 1.0 to 5.0), a fact that was not confirmed with the Sindhi cows used in this experiment.

In the present study, ovulation between groups (Table 2 and Figures 3 and 4) could not be discussed because the number of animals used in the treatments $(\mathrm{n}=8)$ was low. Regarding ovulation rate, Souza et al. (2009) assessed 96 Holstein cows synchronized with $\mathrm{CIDR}^{\circledR}$ and $400 \mathrm{IU}$ eCG on day 8 and found no significant difference between groups $(84 \%$ and $87.5 \%, P=0.61)$. In their experiment, the level of milk production did not affect the concentration of progesterone and pregnancy rate, and there was also no interaction between the eCG and level of milk production.
However, in the same study there was a positive interaction between the eCG and BCS: animals that had a low BCS $(\leq 2.75$ on the scale from 1.0 to 5.0 ) responded best to the use of eCG, demonstrating that this gonadotropin may also be used in protocols for FTAI in cow milk production, improving the reproductive and productive efficiency of these animals. Many of continued reports in the literature indicate the use of eCG to promote increase in large luteal cells, which are responsible for about $80 \%$ of the synthesis of progesterone (P4) giving it greater volume and greater capacity to produce P4 (Souza et al., 2009) and, consequently, increased plasma concentrations of

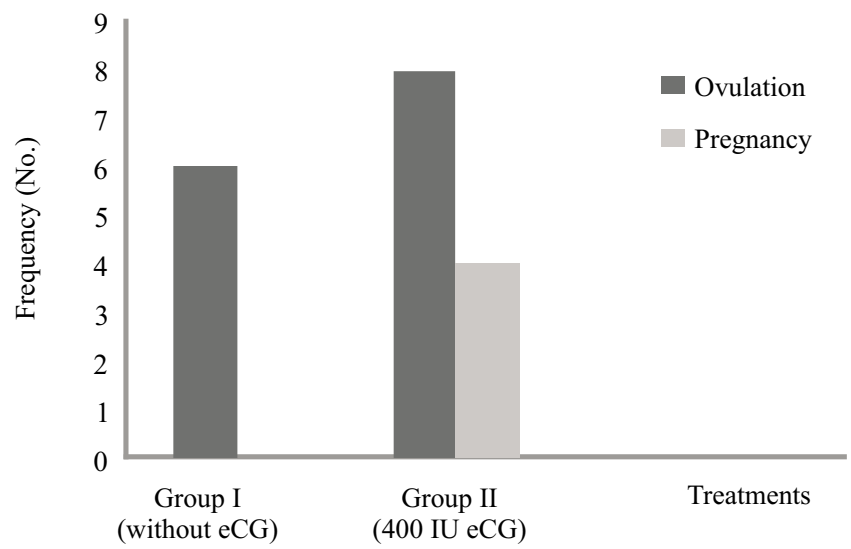

Figure 3 - Ovulation and pregnancy frequencies of 16 Sindhi cows treated in the experiment.

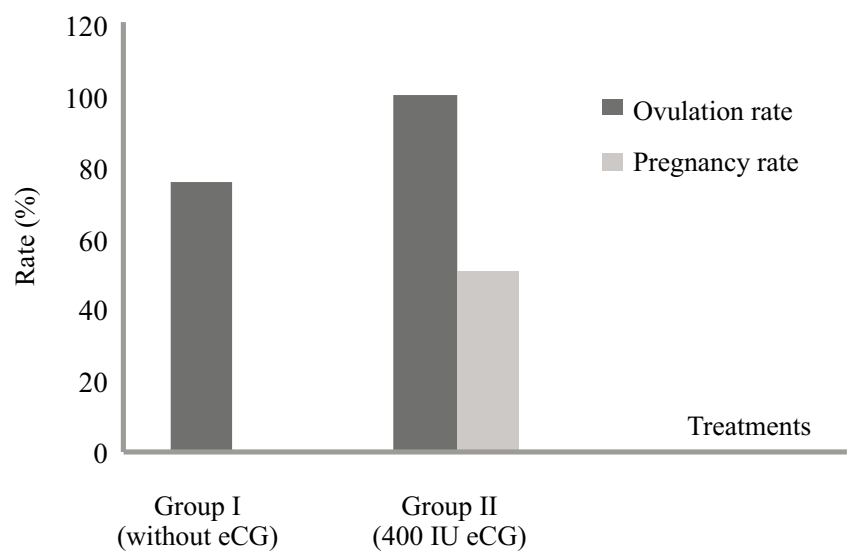

Figure 4 - Ovulation and pregnancy rates of 16 Sindhi cows treated in the experiment.

Table 2 - Frequency of ovulation and pregnancy for groups observed in the experiment

\begin{tabular}{lcccccc}
\hline \multirow{2}{*}{ Parameters } & \multicolumn{3}{c}{ Group I } & \multicolumn{2}{c}{ Group II } \\
\cline { 2 - 7 } & Total frequency & Relative frequency & Percentage & Total frequency & Relative frequency & Percentage \\
\hline Ovulation & 6 & 0.75 & 75 & 8 & 1 & 100 \\
Pregnancy & 0 & 0 & 0 & 4 & 0.50 & 50 \\
\hline
\end{tabular}


progesterone (luteal greater mass) after completion of FTAI in order to improve conception rates (Porto Filho, 2004). Marques et al. (2003) observed an increase in plasma concentrations of $\mathrm{P} 4$ twelve days after ovulation in beef cows that received $400 \mathrm{IU}$ eCG associated with P4 intravaginal implant for FTAI $(8.1 \pm 0.9 \mathrm{ng} / \mathrm{mL} ; \mathrm{P}<0.05)$. The results of Baruselli et al. (2004b) corroborate these findings in heifers. Animals treated with $400 \mathrm{IU}$ eCG on day 8 associated with $\mathrm{P} 4$ intravaginal implants had higher plasma concentrations of progesterone than those not treated $(1.3 \pm 0.2$ and $3.4 \pm 0.6 \mathrm{ng} / \mathrm{mL}, \mathrm{P}<0.05)$. According Baruselli et al. (2004a,b), the administration of eCG can improve the effectiveness of FTAI protocols, so the use of eCG at the time of $\mathrm{P} 4$ intravaginal implant removal has been an alternative to increase conception rates and pregnancy in heifers Bos indicus subjected to FTAI. Thus, several authors have observed an increase in pregnancy rates with the use of eCG. Bó et al. (2001) achieved pregnancy rates of 71.4\% in cows that received eCG and $46.6 \%$ in those which did not received it. Sá Filho et al. (2010a,b) observed a significant increase in pregnancy rates in Nellore lactating anestrus cows $(25 \%$ and $46.2 \%, P=0.07)$ and Nellore cyclic and acyclic heifers $(36.8 \%$ and $50.0 \%, \mathrm{P}=0.04)$ treated with eCG. Likewise, Marques et al. (2004) apud Baruselli et al. (2004d) also observed an increase in pregnancy rate in Nellore cyclic heifers treated with eCG (15.7\% and 34.9\%). In the present study, pregnancy between groups (Table 2 and Figures 3 and 4) could not be discussed because the number of animals used in the treatments $(\mathrm{n}=8)$ was low. Final pregnancy rate observed in this study was low (25\%), and this fact may be related to the advanced age of cows (10 years on average), along with the long period in which they were not pregnant ( 3 years) for being used as embryo donors in FTET programs, and also due to the time of FTAI 36 hours after the inducing ovulation on day 9 .

However, the effects of eCG on pregnancy rates after FTAI in cattle were inconsistent (Sá Filho et al., 2010a). The positive effect of eCG has been most evident in cows that are in anestrus or low body condition score (Cutaia et al., 2003; Souza et al., 2009), not only on pregnancy rates, but also on other reproductive parameters analyzed. In a study with 1984 animals, Baruselli et al. (2004c) evaluated the interaction between $\mathrm{BCS}$ and $\mathrm{eCG}$ on pregnancy rates, and observed that they were only improved by eCG in cows with low $\mathrm{BCS}(\leq 2.5$; without $\mathrm{eCG}=40.7 \%$ and $\mathrm{eCG}=$ $55.4 \%, \mathrm{P}>0.05$ ). Likewise, Cutaia et al. (2003), evaluating the responses to the use of $\mathrm{CIDR}^{\circledR}$ and $400 \mathrm{IU}$ eCG in cows that had a corpus luteum, cows that had follicles larger than $8 \mathrm{~mm}$ in diameter, and cows that had no palpable structures. When the authors compared pregnancy rates between the control group (which did not receive eCG) and treated group, they found that in cycling animals (with CL), the eCG was not significant (52.7\% and 59.6\%), but in those which had only follicles and those which had no palpable structures, the eCG significantly influenced the pregnancy rate (31.3 and $50.9 \%$ and 30.6 and $54.2 \%$, respectively), indicating that the effect of eCG may be beneficial in anestrous cows, and may become more significant in animals with intense degree of anestrus. Consequently, the use of eCG in FTAI protocols can be more effective in herds with a high proportion of anestrous cows, cows with low BCS, or both (Sá Filho et al., 2010a). In the present study, the treatment with this gonadotropin was not efficient in improving the reproductive parameters analyzed. However, the number of animals used was small $(n=16)$, which may have affected the results. Thus, further studies on the reproductive physiology of Sindhi cows with a greater number of animals should be conducted to better understand the factors that influence the fertility of this breed when subjected to FTAI protocols, and thus improve reproductive efficiency indicators in these animals.

\section{Conclusions}

The efficiency of FTAI protocols in Sindhi breed animals may be dependent on the time of FTAI and the time of ovulation, and the time of 36 hours after application of inducing ovulation to perform the AI was not effective in promoting satisfactory pregnancy rates. The administration of $2 \mathrm{mg}$ of estradiol benzoate associated with P4 intravaginal implant at the beginning of treatment caused follicular atresia and synchronized emergence of a new wave of follicular growth in all Sindhi cows subjected to the FTAI protocol. The effect of eCG on Sindhi cows synchronized for FTAI was not efficient in improving the reproductive parameters analyzed. No conclusions can be drawn about ovulation and pregnancy rates because the number of animals used in treatments was low, so more research is needed with a larger number of these animals.

\section{Acknowledgements}

The authors thank the Institute of Animal Science of Universidade Federal Rural do Rio de Janeiro for providing the Sindhi animals and infrastructure support for this study; CAPES/REUNI, for the Master's fellowship grant to the first author; and the Department of Animal Breeding and Evaluation of Universidade Federal Rural do Rio de Janeiro for the support for this research. 


\section{References}

BARUSELLI, P.S.; MARQUES, M.O.; MADUREIRA, E.H. et al. Ovarian superovulation in embryo recipients to improve the number of corpus luteum, progesterone concentration and pregnancy rates. Acta Scientiae Veterinariae, v.28, p.218 [abstract], 2000.

BARUSELLI, P.S.; MARQUES, M.O. Programas de sincronização da ovulação em gado de corte: In: SIMPÓSIO DE REPRODUÇÃO BOVINA - SINCRONIZAÇÃO DE ESTROS EM BOVINOS, $1 .$, 2002, Porto Alegre. Anais... Porto Alegre, 2002. p.41-60.

BARUSELLI, P.S.; REIS, E.L.; MARQUES, M.O. et al. The use of hormonal treatments to improve reproductive performance of anestrus beef cattle in tropical climates. Animal Reproduction Science, v.82, p.479-486, 2004a.

BARUSELLI, P.S.; REIS, E.L.; CARVALHO, N.A.T. et al. eCG increase ovulation rate and plasmatic progesterone concentration in Nellore (Bos indicus) heifers treated with progesterone releasing device. In: INTERNATIONAL CONGRESS ON ANIMAL REPRODUCTION, 16., 2004, Budapeste, Hungria. Proceedings... Budapeste, Hungria, 2004b. v.1, p.117.

BARUSELLI, P.S.; MADUREIRA, E.H.; MARQUES, M.O. et al. Efeito do tratamento com eCG na taxa de concepção de vacas Nelores com diferentes escores de condição corporal inseminadas em tempo fixo (Análise retrospectiva). In: REUNIÃO ANUAL DA SOCIEDADE BRASILEIRA DE TRANSFERÊNCIA DE EMBRIÕES, 18., 2004, Barra Bonita. Anais... Barra Bonita, 2004c. v.32. p.228.

BARUSELLI, P.S.; BÓ, G.A.; REIS, E.L. et al. Inseminação artificial em tempo fixo em bovinos de corte. In: SIMPÓSIO INTERNACIONAL DE REPRODUÇÃO ANIMAL APLICADA, 10., Londrina, 2004. Anais... Londrina, 2004d. p.155-165.

BARUSELLI, P.S.; GIMENES, L.U.; SALES, J.N.S. Fisiologia reprodutiva de fêmeas taurinas e zebuínas. Revista Brasileira de Reprodução Animal, v.31, n.2, p.205-211, 2007.

BARUSELLI, P.S.; JACOMINI, J.O.; SALES, J.N.S. et al. Importância do emprego da eCG em protocolos de sincronização para IA, TE e SOV em tempo fixo. In: SIMPÓSIO INTERNACIONAL DE REPRODUÇÃO ANIMAL APLICADA, 3., 2008, Londrina. Anais... Londrina, 2008. p.146-167.

BINELLI, M.; THATCHER, W.W.; MATTOS, R. et al. Antiluteolytic strategies to improve fertility in cattle. Theriogenology, v.56, p.1451-1463, 2001.

BÓ, G.A.; ADAMS, G.P.; PIERSON, R.A. et al. Follicular wave dynamics after estradiol-17b treatment of heifers with or without progestogen implant. Theriogenology, v.41, p.1555-1569, 1994.

BÓ, G.A.; ADAMS, G.P.; CACCIA, M. et al. Ovarian follicular wave emergence after treatment with progesterone and estradiol in cattle. Animal Reproduction Science, v.39, p.193-204, 1995.

BÓ, G.A.; CUTAIA, L.; BROGLIATTI, G.M. et al. Programas de inseminacion articial a tiempo fijo en ganado bovino utilizando progestagenos y estradiol. In: SIMPÓSIO INTERNACIONAL DE REPRODUÇÃO ANIMAL, 4., 2001, Córdoba. Proceedings... Córdoba, 2001. p.117-136.

BÓ, G.A.; MORENO, D.; CUTAIA, L. et al. Manipulação hormonal do ciclo estral em doadoras e receptoras de embrião bovino. Acta Scientiae Veterinariae, v.32, p.1-22, 2004.

BRIDGES, P.J.; LEWIS, P.E.; WAGNER, W.R. et al. Follicular growth, estrus and pregnancy after fixed-time insemination in beef cows treated with intravaginal progesterone inserts and estradiol benzoate. Theriogenology, v.52, p.573-583, 1999.

CARVALHO, B.P. Superovulação de vacas Red Sindi (Bos taurus indicus) com três diferentes doses de FSH. 2009. 57f. Dissertação (Mestrado em Ciência Animal) - Universidade Estadual do Norte Fluminense Darcy Ribeiro, Rio de Janeiro.

CARVALHO, J.B.P. Sincronização da ovulação com dispositivo intravaginal de progesterona $\left(\right.$ CIDR $\left.^{\circledR}\right)$ em novilhas Bos indicus, Bos indicus $\mathbf{x}$ Bos taurus e Bos taurus. 2004. 124f. Tese
(Doutorado em Medicina Veterinária) - Faculdade de Medicina Veterinária e Zootecnia, Universidade de São Paulo, São Paulo.

CUTAIA, L.; TRÍBULO, R.; MORENO, D. et al. Pregnancy rates in lactating beef cows treated with progesterone releasing devices, estradiol benzoate and equine chorionic gonadotropin (eCG). Theriogenology, v.59, p.216, 2003 (IETS).

DRIANCOURT, M.A. Regulation of ovarian follicular dynamics in farm animals. Implications for manipulation of reproduction. Theriogenology, v.54, p.1211-1239, 2000.

DUFFY, P.; CROWE, M.A.; AUSTIN, E.J. et al. Effect of eCG or estradiol at or after norgestomet removal on follicular dynamics, estrus and ovulation in early post-partum beef cows nursing calves. Theriogenology, v.61, p.725-734, 2004.

EVANS, A.C.O.; KOMAR, C.M.; WANDJI, S.A. et al. Changes in androgen secretion and luteinizing hormone pulse amplitude are associated with recruitment and growth of ovarian follicles during the luteal phase of the bovine estrus cycle. Biology of Reproduction, v.57, p.349-401, 1997.

GIBBONS, J.R.; WILTBANK, M.C.; GINTHER, O.J. Relationship between follicular development and the decline in the folliclestimulating hormone surge in heifers. Biology of Reproduction, v.60, p.72-77, 1999 .

LANE, E.A.; AUSTIN, E.J.; ROCHE, J.F. et al. The effect of estradiol benzoate on synchrony of estrus and fertility in cattle after removal progesterone-releasing intravaginal device. Theriogenology, v.55, p.1807-1818, 2001.

MARAÑA, D.; CUTAIA, L.; PERES, L. et al. Ovulation and pregnancy rates in postpartum Bos indicus cows treated with progesterone vaginal inserts and oestradiol benzoate, with or without eCG and temporary weaning. [abstract]. Reproduction, Fertility and Development, v.18, p.116-117, 2006.

MARQUES, M.O.; REIS, E.L.; CAMPOS FILHO, E.P. et al. Efeitos da administração de eCG e de Benzoato de Estradiol para sincronização da ovulação em vacas zebuínas no período pósparto. In: SIMPÓSIO INTERNACIONAL DE REPRODUCCIÓN ANIMAL, 5., 2003, Córdoba, Argentina. Proceedings... Córdoba, Argentina, 2003. p.392.

MINISTÉRIO DA AGRICULTURA, PECUÁRIA E ABASTECIMENTO - MAPA. Artigos técnicos - Animal: bovinos e bubalinos. Available at: <http:www.agricultura.gov.br/animal/ especies/bovinos-e-bubalinos>. Accessed on: May 10, 2010.

PORTO FILHO, R.M. Sincronização da ovulação para a inseminação artificial em tempo fixo (IATF) durante a estação reprodutiva desfavorável em fêmeas bubalinas. 2004. 97f. Tese (Doutorado em Reprodução Animal) - Faculdade de Medicina Veterinária e Zootecnia, Universidade de São Paulo, São Paulo.

ROCHA, J.L. Sincronização hormonal da onda folicular e do estro em novilhas de corte mestiças monitoradas por radiotelemetria. 2000. 125f. Tese (Doutorado em Reprodução Animal) - Faculdade de Medicina Veterinária e Zootecnia, Universidade de São Paulo, São Paulo.

SÁ FILHO, M.F.; REIS, E.L.; VIEL Jr., J. O. et al. Follicular dynamics in anestrous lactating Nellore treated with ear implant, eCG and GnRH. Acta Scientiae Veterinariae, v.32, p.235, 2004.

SÁ FILHO, M.F.; AYRES, H.; FERREIRA, R.M. et al. Equine chorionic gonadotropin and gonadotropin-releasing hormone enhance fertility in a norgestomet-based, timed artificial insemination protocol in suckled Nellore (Bos indicus) cows. Theriogenology, v.73, p.651-658, 2010a.

SÁ FILHO, M.F.; TORRES-JÚNIOR, J.R.S.; PENTEADO, L. et al. Equine chorionic gonadotropin improves the efficacy of a progestin-based fixed-time artificial insemination protocol in Nellore (Bos indicus) heifers. Animal Reproduction Science, v.118, p.182-187, 2010b.

SALES, J.N.S.; CREPALDI, G.A.; GIROTTO, R.W. et al. Fixed-time AI protocols replacing eCG with a single dose of FSH were less effective in stimulating follicular growth, ovulation, and fertility in suckled-anestrus Nellore beef cows. Animal Reproduction Science, v.124, p.12-18, 2011. 
SANTIAgO, A.A. A epopeia do Zebu. 2009. Available at: $<$ www.abcz.org.br>. Accessed on: June 26, 2011.

SOUZA, A.H.; MARTINS, C.M.; TORRES JUNIOR, J.R.S. et al. Efeito do eCG e do cipionato de estradiol em protocolos para inseminação artificial em tempo fixo em vacas holandesas de alta produção. In: REUNIÃO ANUAL DA SOCIEDADE BRASILEIRA DE TECNOLOGIA DE EMBRIÕES, 20., 2006, Araxá. Proceedings... Araxá, 2006. v.34, p.404.
SOUZA, A.H.; VIECHNIESKI, S.; LIMA, F.A. et al. Effects of equine chorionic gonadotropin and type of ovulatory stimulus in a timed-AI protocolo on reproductive responses in dairy cows. Theriogenology, v.72, p.10-21, 2009.

WILDMAN, E.E.; JONES, G.M.; WAGNER, P.E. et al. A dairy cow body condition scoring system and its relationship to selected production characteristics. Journal of Dairy Science, v.65, p.495-501, 1982. 